\title{
DIVINE KNOWLEDGE: COMPARISONS AND CONTRASTS WITH HUMAN KNOWLEDGE
}

\author{
Richard Sturch
}

\begin{abstract}
Summary
Can we understand divine knowledge by analogy with human knowledge? This essay approaches the question by examining two forms of human knowledge: knowledge by creation and by understanding of classes of things. It is suggested that two other forms of human knowledge, memory and inference, may be less helpful as analogies for divine knowledge: if God knows future choices of free agents, this entails knowledge by experience. The essay examines the implications of divine knowledge of the future for human freedom and discusses the question of 'middle knowledge' of non-actual free choices. Certain problems raised by knowledge of temporal events suggest (but do not entail) that God is timeless.
\end{abstract}

\section{Introduction}

Philosophers and theologians have long had to steer a course between anthropomorphism and anti-anthropomorphism. The Bible itself is clearly anthropomorphic in its positive statements: God is depicted as having a right hand, ears, feet, a back, and so on. But the Bible is also clear that God is profoundly unlike us-'"To whom will you liken me?" says the Holy One' (Is. 40:25); and philosophically-minded theologians have frequently taken full advantage of this, so that God has been identified with the Absolute of Idealism, or with 'Being itself'.

Now this has consequences for discussions of divine attributes. Not only do we get theories of symbolism, analogical predication and the like; we find problems arising when we try to understand particular attributes. Can we, for instance, seek to understand-or at least discuss-the divine Eternity by comparing it to human existence in time, or should we think of God as entirely outside any kind of time, or somewhere in between? Paul Helm is of course a notable contributor to that 
debate. Again, can we seek to understand-or at least discussthe divine Omniscience by way of analogy with human knowledge? That is the question I wish to raise here. It is not a new question. ${ }^{1}$ Already from the tenth century, Muslim philosophers and theologians were arguing about it, and Averroes was complaining that the latter were 'making God into an eternal man, and man into a mortal God'. ${ }^{2}$ Certainly the divine knowledge in which Averroes believed, which instead of being caused by the world actually brought the world into being, must be very unlike anything human beings have.

Perhaps we could begin by asking what models based on human knowledge we might use in understanding divine knowledge (I am dealing here with 'knowledge that' rather than 'knowledge how'). Three suggest themselves: experience, memory and inference. (A fourth, knowledge imparted by others, even if it can be treated as separate from these three, is clearly inapplicable to God.) Of course, there have been many debates over the years about the nature of these, but they will do as a start.

\section{The Model of Experience}

In ancient and mediaeval times, people were disturbed by the first model, knowledge by experience. It seemed to make God dependent for his knowledge upon contingent things, although he himself was not contingent but necessary. Some were not at all sure that God could know particulars. He fully understood the nature of a broad bean; but could he know any one specific broad bean? Hence Avicenna's baffling opinion that God has universal knowledge of particulars, which might possibly mean

\footnotetext{
${ }^{1}$ The final form of the Muslim debate can be found in S. van den Bergh's edition of Averroes, Tahafut al-Tahafut (2 Vols.; London: Luzac, 1954). For recent discussions of the subject, I may mention W.L. Craig, Divine Knowledge and Human Freedom (Leiden: Brill, 1990); W. Hasker, God, Time and Knowledge (Ithaca: Cornell UP, 1989); N. Pike, God and Timelessness (London: Routledge, 1970); A. Plantinga, God, Freedom and Evil (London: Allen \& Unwin, 1975); R. Swinburne, The Coherence of Theism (Oxford: OUP, 1977; 2nd ed. 1993); idem, The Christian God (Oxford: OUP, 1994); L.T. Zagzebski, The Dilemma of Freedom and Foreknowledge (New York/ Oxford: OUP, 1991).

2Tahafut al-Tahafut, Vol. I, 283.
} 
that he does indeed know this broad bean, but only in respect of those universals in which it participates. God's knowledge was eternal, necessary, and noble; singulars are temporal, contingent, and (often) vulgar.

There were various possible answers to this. Algazel said firmly that if the knowledge of inanimate objects that we receive is a perfection in us, not an imperfection or a subjection to them, why should not this be true of God?3 ${ }^{3}$ On the other hand, we find Aquinas apparently teaching a different kind of knowledge in God-what we might call knowledge by creation:

God knows other things in so far as he is their cause. Now singular things are God's effects; he causes them, in so far as he makes them to actually be. He therefore knows things other than himself not only universally but in the singular. ${ }^{4}$

I am not sure of the exact interpretation of Aquinas; like Averroes, he thought of God's knowledge as itself creative. But that does not matter; the idea of knowledge by creation is what we are concerned with. Must this be peculiar to God, and hence unable to be treated in any way anthropomorphically? I incline to say No. We may possibly find human analogies, in for example our knowledge of our own mental images. Some of these we do not just have but conjure up; this is perhaps the nearest we get to creation ex nihilo. And if I frame the mental image of a green rhinoceros, I do not need to inspect it to see whether it really is the image of a green rhinoceros. My knowledge of this is immediate, dependent only upon my will to conjure up this particular kind of image. Knowledge of one's decisions might also be an analogy; if I decide to vote for Wintergreen I do not need introspection to know whom I have decided to vote for! But perhaps mental images are enough.

\section{The Model of $A$ Priori Knowledge}

Does this, however, apply to the divine knowledge, already mentioned, of the idea of a broad bean, before God created any? We seem to need knowledge that is not simply by

${ }^{3}$ Tahafut al-Tahafut, Vol. I, 282.

${ }^{4}$ Summa Contra Gentiles, 1:65:2. 
creation; could God create his own idea of anything without an infinite regress? (If he creates the bean via his knowledge of its idea, then he creates the idea by knowledge of its meta-idea, and so on.) We seem to have two possible explanations of such knowledge. Either all ideas, all universals perhaps, are somehow contained within God, and he knows them by knowing himself, or he knows them all a priori, and not by creating them-which for convenience I shall call knowledge by understanding. This is a term used by Aquinas for the knowledge God has of things that could come to be but in fact never will. 5 I should have thought, though, that it extended also to things which would be-such as broad beans; the difference is not in God's knowledge, but in the fact that he has decided to create broad beans and not these other things.

Once again we may have an analogy in our own life, the knowledge we have of the a priori. I say 'may' because of the arguments that have raged over whether or not there is such a thing as knowledge of the a priori, and if so, what its nature is. God's knowledge by understanding, of course, would be more extensive than ours, not only greater in quantity but more wide-ranging, in that we have far less knowledge of the nature of possible things than God has. But it might not be different in kind.

Can we now, with these special forms of divine knowledge, by creation and by understanding, dispense with the forms we began with, and so after all get away from anthropomorphism? Do we still need to ascribe to God knowledge by experience, memory, and inference? It might seem in a way desirable if we could, as it would mean that God's knowledge was derived entirely from his creative will and his understanding of the infinity of all possibilities-two things in which he is unique, or at least to which only doubtful analogies can be found in the knowledge possessed by human beings.

I am inclined, however, to reply: No, we do need to ascribe to the Lord some at least of these other, humbler forms of knowledge. Memory, indeed, is doubtful. I myself believe that God is in no sense 'in time', in which case he has no past and therefore no memory (or precognition, for that matter). The Bible undoubtedly speaks of him as 'remembering', but this

${ }^{5}$ Summa Contra Gentiles, 1:66:8. 
could be taken as describing him sub specie temporis; it refers to times when his knowledge of things that to us (not to his eternity) are past comes into play and affects us. Perhaps more interesting is the possibility of his forgetting; Jeremiah speaks of him as 'remembering their sins no more' (Je. 31:34). But few have taken this literally; usually it has been supposed that this is practical remembering, putting memory into action. However, if God is indeed 'in time', then presumably we have to ascribe memory to him.

\section{The Model of Inference}

What about inference? If God has what I have called knowledge by understanding-complete knowledge of anything knowable a priori-does he need inferential knowledge at all? All mathematics, for example, could be known directly without the need human mathematicians have to infer some propositions from others. ${ }^{6} \mathrm{He}$ would know, of course, that such-and-such postulates implied such-and-such theorems; but he would not need to use the implications in order to see the truth of the theorems. But might knowledge by inference still be needed for his knowledge of unrealised possibilities? Would not God know what would have followed on from $X$ (where $X$ did not in fact occur) by inference from $X$ by way of the laws of nature? He knows (say) whether this broad bean plant would have survived if it had been watered properly (which it was not) by inference, but using as a premise the false proposition that it was in fact watered.

This is, on the whole, my own opinion. There are problems in it, though; especially over the nature of truth when applied to counter-factuals. There might be an alternative, however. Aquinas takes this kind of knowledge to be possible because things which do not actually exist are still in the power of God or of some created being. ${ }^{7}$ Hence in understanding his own power God understands all that might be done by it, and in understanding the powers of created things he understands all that might be done by them. Hence knowledge by inference

\footnotetext{
6I leave to better logicians than I to decide whether this has any bearing on how, if at all, Gödel's Theorem affects the divine omniscience.

${ }^{7}$ Summa Theologiae 1, 14, 9.
} 
is unnecessary even for God's knowledge of the unrealised; he knows directly what would have happened (say) if the bean plant had been watered properly (for he knows the powers of beans and of water), or indeed what would have happened if the universe had been created with different laws (for he knows his own creative powers). On the other hand, it could be replied that God can fully understand his own and other beings' powers only by inferring conclusions from basic knowledge of those powers, so that this view really reduces to the previous one. I incline to think so myself, but defer to the reader's judgement.

\section{Knowledge of the Future}

Can God manage without knowledge by experience (doubtless very different from our own experiences)? God knows all possible worlds by inference and/or knowledge of understanding, and he knows which of these is the real world by his act of creation; surely, therefore, he needs no experience?

However, there is one reason that points very strongly in the direction of knowledge by experience, even for God. For God is usually supposed to know the future, including the free choices of human agents (and any other rational beings). He cannot know these by creation, for all he creates is the agent, the circumstances, and the agent's power to choose. He does not create the choice itself; that would take away the agent's freedom. Equally, he cannot know these choices by understanding (or inference), for that would mean they were determined by events outside the agent's control, and once again freedom would be denied. (I am speaking here as an Arminian. A Calvinist, or any other kind of determinist, will have no difficulty here.) On the other hand, if God has the power of prevision, or if he is outside of time but aware of what goes on within it, he can be aware of free choices just as we can (though we of course can only know them after they have happened). And this implies that he does have knowledge by experience, and so that he can also be aware by experience of other things in the world (which he might also of course know by other means as well).

It may be that there are other events in the universe which God can only know by experience. Certain events on the 
quantum level are thought to be physically undetermined. Not even God, therefore, could know them by inference or understanding. He might just possibly know them by creation, though. They would then be determined by a hidden variable-God's will-but this would operate in such a way as always to ensure that they followed only statistical patterns as far as scientific investigation could tell.

This seems rather improbable to me, and rather like Gosse's Omphalos-God deliberately confusing scientists for no obvious reason; but I cannot see any actual impossibility in it. It was indeed the view of the late Eric Mascall that this was what actually happened. 8

There is perhaps a certain difficulty over the idea of God's creating free agents and knowing all about them by creation except their free choices. That would take us into the theology and philosophy of creation rather than of omniscience. I might, however, suggest that here too there could be a very faint analogy in our own lives. I mentioned the framing of mental images as a possible analogy for creation ex nihilo, and our knowledge of them as a possible analogy to knowledge by creation. Now there is a well-known problem about mental imagery, the Problem of the Speckled Hen. If I imagine a speckled hen, must I also imagine her as having (say) eighty-four speckles? The natural answer is surely No. I do not determine the exact number of speckles she has, and it is not clear that I should even be able to count them; it looks suspiciously as if she had no exact number of speckles. Similarly, God might create people who choose between $X$ and $Y$ without there being any certainty of which they choose, until they actually do so. But this is speculation.

\section{Foreknowledge and Freedom}

Another well-known problem is whether God can know the future at all without imperilling human freedom. There is one classic argument for this which is certainly fallacious. It has been held that if God knew beforehand (say) that Napoleon would return from Elba, then it was a necessary truth that

8E.L. Mascall, Christian Theology and Natural Science (London: Longmans, 1956) 201. 
Napoleon would return; therefore Napoleon had no free will in the matter. This is of course false; the necessity applies, not to Napoleon's decision, but to the entire proposition 'If God knew that Napoleon would return from Elba, then Napoleon would return from Elba'; and similar statements are equally necessary when applied to knowledge other than God's and knowledge of events other than the future. For instance, it is a necessary truth that if I know that Napoleon returned from Elba, then Napoleon did return. Indeed, we need not bring knowledge into it at all. It is also a necessary truth that, if Napoleon returned from Elba, then he did return from Elba. None of these trivial truths have the slightest bearing on Napoleon's freewill.

An argument of Paul Helm implies that this is incorrect because statements about the past are themselves necessary. ${ }^{9}$ Hence if God knew in 1800 that Napoleon would return, this was a necessary truth in 1813; hence the antecedent as well as the entire proposition in 'If God knew in 1800 that Napoleon would return from Elba, then Napoleon would return from Elba' is necessary, and therefore so is the consequent. But this will not do either. For statements about the past are only claimed to be necessary because they are unalterable. But the future is unalterable too. Where it differs from the past is in that it can be affected by the present, which the past (normally) is not. But if God has foreknowledge, then one particular feature of the past, namely, God's foreknowledge (together with any events dependent on it, such as prophecies), can be affected by the present, and so is no different from the future, and no more necessary than it.

Nor is there strength in Pike's argument ${ }^{10}$ that if God knew in advance that Jones would freely choose to mow his lawn on a certain day, then it would be within Jones' power, by freely choosing not to mow that day, to cause God to have held a false belief. But as has been pointed out by (for example) Plantinga, all this shows that it was within Jones' power to do something such that, if he had done it, a belief that God did in

${ }^{9}$ Eternal God: a study of God without time (Oxford: Clarendon, 1988), 101 and elsewhere.

${ }^{10}$ God and Timelessness, $72 \mathrm{ff}$. 
fact hold earlier would have been false. But in that case God would not have held it. ${ }^{11}$

William Hasker ${ }^{12}$ puts it differently, but no more convincingly. If Clarence eats a cheese omelette for breakfast, there is a circumstance (God's foreknowledge that he would do so) which logically precludes his refraining from eating the omelette. Therefore, unless Clarence can alter the past (and surely he cannot) he is not free to refrain. This is no improvement. Lots of circumstances logically preclude his refraining-e.g., that his wife is watching him eat the omelette, that his (accurate) biographers later record that he did indeed eat the omelette, that the statement 'Clarence had cheese omelette for breakfast' is true, and so on. None affect his freedom.

More serious is an argument of Richard Swinburne. ${ }^{13}$ If person $S$ can do something at time $\mathrm{T}^{1}$, then he can bring it about that God believed at the earlier time $T$ that he, $S$, would do that thing. In other words, backward causation would be possible: $S$ would be able to bring about a past state. I myself (unlike Swinburne) agree with those who say God is not in time at all, and that the state of affairs which S brings about is not therefore truly past. And there is some suggestion from quantum physics that in that weird realm backward causation may actually occur. But the argument can be taken further if God can reveal the future. God, knowing (non-temporally) that $\mathrm{S}$ would do whatever it was, might reveal this before $\mathrm{T}^{1}$. Christians have of course usually believed that this has happened. Most Biblical predictions are conditional-indeed, often intended to ensure that they do not come true-but some are absolute. Jesus knew in advance, for example, that before the cock crew, Peter would have denied him three times. (This can hardly be ascribed simply to Jesus' knowledge of the character of Peter, as Hasker does; 14 the number and timing of the denials rule that out.) And the nature of God's eternity does not affect the fact that Jesus's knowledge and prediction took place before Peter did any denying. Perhaps, then, we ought

\footnotetext{
11Plantinga, God, Freedom and Evil, 70.

${ }^{12} \mathrm{God}$, Time and Knowledge, 131.

${ }^{13}$ The Coherence of Theism, 174ff.

${ }^{14}$ God, Time and Knowledge, 195.
} 
simply to say that backwards causation is possible in this particular instance.

Here another argument of Hasker is important. ${ }^{15}$ Assume that I can bring about past states that really have occurred: can I also have the power to bring about past states that did not occur? It seems that we have to say Yes. Suppose Clarence is free to choose whether or not to eat that omelette. Then he has the power both to bring it about that God had always believed that he would eat it, and to bring it about that God had always believed he would not eat it. But God has in fact always believed one of these two (let us say, that Clarence would eat it). How then was it in Clarence's power to bring it about that God did not, ever, believe any such thing?

We should not really be bothered about this. Forget God and the past. Clarence has the power both to ensure that his biographers will record an omelette at his breakfast and to ensure that they will not. But they will in fact record only one of these-say, that he did eat it. How, then, did Clarence ever have the power to ensure that they would say he did not eat it? Well, he did. That's part of what is meant by free will. It leads to no difficulty over the biographers, nor should it over God.

\section{Backward and Circular Causation}

However, though we may not be troubled by this limited kind of backwards causation in itself, the next step leads us into intellectual knots. What about God's use of his foreknowledge? Science fiction readers will know of similar problems raised by the idea of time travel, but let us set that aside: time travel does not seem to happen; but surely God's foreknowledge does. Take Peter's denials again. When Jesus revealed the result of Peter's free choices before Peter made them, might this not affect Peter's decision? In fact it did not; Peter forgot the prediction until too late. But he need not have done so. Even if God always makes sure that such predictions do not affect the decision, need he always do so? Is he not a free agent in the matter? And if he did not take this precaution, would we not have to choose between very uncomfortable dilemma-horns? Either we must deny our freedom (and even that might not

${ }^{15}$ God, Time and Knowledge, esp. $127 \mathrm{ff}$. 
suffice, as we shall see); or, if our freedom remained, by choosing to act otherwise than predicted we should have made God either mistaken or a liar.

Normally in such cases I look to imaginative fiction for assistance. The nearest I can get is in Diana Wynne Jones' The Crown of Dalemark, in which Mitt, the heir to that crown, is asked whether he will take the dynastic name of Amil-which he knows (thanks in this case to time travel, not divine revelation) he will in fact take. 'Mitt knew it was a real choice, even if he had been told which way he chose. He weighed it up.... "I'll take Amil," he said.' 16 In other words, as the decision was a genuinely free one, then it was not affected by Mitt's knowledge. It was affected by his weighing up the pros and cons. Perhaps this is the correct answer. Human freedom is preserved, because if the prediction determines the decision, that decision was not in truth free (of course, not all our actions are free!); and conversely, if the decision foreseen and predicted really was free, then it was made without being determined by the prediction. If Peter had remembered Christ's words, he would have gone ahead with his denials just the same. But I am not altogether happy about this. Mitt's seems a very queer state of mind to be in. But then to have one's actions foretold to one is likely to produce a queer state of mind.

Are we heading for, not simply backward, but circular causation? Swinburne 17 treats the former as entailing the latter; and though he does not explain his reasons, I think I can see what they might be. If Mitt, or Peter, by an act of free will, does something, and God knows this, and reveals that he will do it, then if he knows of this it might, even must, affect his action, even if it does not determine it. His action's background is different-for instance, his brain cells are not in the state they would have been otherwise. Yet that background depends causally on the prediction, and thus on the action itself.

We have three propositions of which any two are compatible but together rule out the third: (1) God knows a future event $X ;(2)$ God predicts a future event $X ;$ (3) a prediction by God can affect whether $X$ happens or not. 1 and 2 together are true in the case of Peter, but not $3 ; 2$ and 3 are true together in the case of a conditional prophecy like Jonah's

${ }^{16}$ D.W. Jones, The Crown of Dalemark (London: Mandarin, 1993) 357.

${ }^{17}$ The Christian God, 82. 
against Nineveh, but not 1; and in most cases, on the normal Christian view of things, 1 and 3 are true without 2 . But 1 seems to be entailed by omniscience, and 3 will surely be true as a rule-cases like those of Mitt or St. Peter are rare!-and 2 most Christians would accept as having happened from time to time. Swinburne resolves the problem by denying that 1 is ever true (unless it is something God intends or which is necessitated by natural law). This seems too drastic. All we require is that the logical incompatibility of the three be maintained. Now on the usual view of omniscience, when human freedom is not involved, God will always know whether 3 is true, and indeed how a prediction will affect the actuality, quite independently of whether $X$ happens or not; for he knows the effects his words will have. He can then choose whether to predict $X$ or not. If he knows his prediction will prevent $X$ from happening, the prediction will of course be conditional. If human freedom is involved, he will not know exactly what effects prediction will have, and prediction will again be conditional. It will have to be conditional; this is a logical necessity-which seems to me to be an advantage over Swinburne's solution. God's actual prevision of the event $X$ is now causally dependent on his (and the human agent's) decisions; but no causal circle is entailed.

But will this apply to another field of foreknowledge which Swinburne has drawn attention to: God's knowledge of his own future acts? For God can choose whether or not to reveal his knowledge of the future to mortals; but he cannot choose whether or not to reveal it to himself. He knows what he knows. If, then, he knows that he will rescue Israel from Egypt, what choice has he in the matter? Perhaps he has none, because he will always do what is best and wisest? But there may not be a best and wisest in all situations, especially if his creatures have free will. It may be that this is one more reason for believing that God is timeless; for in that case of course he would not foresee his own acts at all, he would merely do them and see, or know, what he did. They would be causally anterior to his knowledge, but not temporally anterior. 18

${ }^{18}$ This subject is discussed at some length in a debate between T. Kapitan and D.P. Hunt in Religious Studies, 28 (September 1992), 30 (January 1994) and 32 (March 1996). 


\section{VIII. 'Middle Knowledge'}

Some wish to ascribe to God more even than foreknowledge. The sixteenth-century idea of 'middle knowledge' has experienced a revival. According to this, besides God's 'free' knowledge of actual particulars-e.g., what actually happened or will happen on such-and-such a time and place-and his 'natural' knowledge of general truths (from which non-actual possibilities can be inferred) he also has a knowledge of nonactual indeterminates-e.g., what so-and-so would have chosen, in her free will, had she been offered a choice which in fact she never was offered. If so (if, that is, God does have 'middle knowledge'), then his knowledge is in one respect utterly unlike that of humans. And this would solve our last difficulty. For God would know exactly how Peter would act if his denials were predicted and how he would act if they were not; there would be no need for a circle of causation, for God's knowledge would be there independently of Peter's free decision. This has also been hailed (e.g., by William Lane Craig ${ }^{19}$ ) as solving the ancient problems of providence and predestination. I may even have unwittingly called on middle knowledge myself in what I was saying earlier about the denials, and God's knowing whether Peter would be affected by Jesus's prediction. (Actually, I think that in this case middle knowledge is not involved; it is only that God knew whether or not Peter would remember the prediction.)

Now a solution to these difficulties would certainly be a gain. But so would the existence of a perpetual-motion machine, which would produce a steady supply of cheap and non-polluting energy, solving many of the world's economic and environmental problems, but which unfortunately happens to be impossible. And there are notorious difficulties with 'middle knowledge'. The most important for Christians is that it makes theodicy far more difficult. For according to the usual (and to my mind correct) procedure for dealing with the problem of evil, God had to make us free if he were to have us truly loving him and truly doing what was good; and if we are free, then not even God can control what we do and prevent us from doing evil if we so decide. But if God has 'middle knowledge' he can know what we would do before creating us.

${ }^{19}$ Divine Knowledge, 242. 
He knew before he created Adam and Eve that they would disobey his command and eat from the tree of knowledge. And therefore he could have created someone else who would (freely) not eat from the tree. As he did not do so, he is responsible for the wrong decision that was made, and for the evils which flowed from it. (Adam and Eve are also responsible of course, for they did freely choose to disobey; but that does not reduce God's responsibility.) I recall a story-Muslim, I think - of a soul in heaven which asked Allah why it was in a lower place than so-and-so. 'Because he lived a long and good life', was the answer, 'whereas you died young.' 'Then why did you not let me live longer?' 'Because I knew if you did, you would fall into sin, and go to hell instead.' (Middle knowledge!) And then voices were heard coming up from hell: 'Then why, Lord, did you not make sure we too died young?' They appear to me to have been justified, unless indeed we accept Plantinga's suggestion that perhaps every possible person has 'transworld depravity'-i.e., that not only do we suffer from original sin but any possible person that God could create would do so too. I can see no reason to believe this. That all finite creatures may be weak and liable to sin is likely enough; that they are bound to is not. I see, therefore, no reason to suppose that 'middle knowledge' is compatible with the normal Free Will Defence.

Of course, this might simply mean that we had to scrap the normal Free Will Defence, though this is not a move I should care for! But there is another problem over 'middle knowledge' - a problem over the reality of the thing which God is said to know. God cannot know-no-one can-something that is logically incoherent. he cannot know the shape of a round square, or the constitutional duties of the King in a republic. And this is what 'middle knowledge' would be. If I am genuinely and relevantly a free agent, then what I would do in an imaginary situation is a complete non-entity. To use the language of 'possible worlds', if I am relevantly free, and might be (but am not) faced with two possibilities over a choice $C$, then there are two or more possible worlds, identical up to the time of $C$, in at least one of which I make choice $C^{1}$ and in at least one of which I make choice $C^{2}$. Since neither is the actual world, and both resemble the actual world to exactly the same extent, no one can say which I would have chosen; there is no 
such thing, and not even an omniscient God could know it. Or, if you prefer, there are two such things, and God knows bothas mere possibilities. He may perhaps know which is more likely; not which is real, because there is no such thing. Counter-factuals can certainly be true or false, but for this truth or falsity they must be grounded somehow in the real world, and the things God is supposed to know by middle knowledge are not.

Craig 20 has defended middle knowledge against this argument by pointing out that even we know all sorts of propositions about non-existent decisions. 'If he really loved you, he would not treat you like that', for example; or 'The butcher would have sold me a pound of minced beef if I'd asked him.' And so we do. But these are not free decisions. A true lover would wish his beloved well, and the idea of mistreating her would not occur to him. The butcher has no reason not to sell people beef; he does not decide or choose to sell it every time a customer turns up. If he did have reason to make a choice at the time of sale-if, let us say, he suspected the beef to be contaminated-we might not be sure whether greed or honesty would triumph, and we should not know whether or not he would have sold it to me.

Let me put it another way, using those possible worlds again. God's natural knowledge lets him see all possible worlds, including those in which I do ask the butcher for the mince. If the butcher is genuinely free in this particular kind of situation, then in one world at least he sells it to me and in one at least he does not. But middle knowledge requires that one of those worlds be in some sense 'real' and the other not. Some have thought that it is resemblance to this actual world that determines that. But in this case both resemble the real world to exactly the same extent. Surely there is no way that even God can say 'A is the more real and B the less real'; they have no distinguishing marks at all. If one is real and the other not, it is for some reason. To quote Aquinas again: 'God knows nonbeings in so far as in some way they have being, namely, in his power, or in their causes, or in themselves.'21 But the butcher's choice in an imaginary situation has being in none of these ways. It is not in God's power, for he has made him free in this

${ }^{20}$ Divine Knowledge and Human Freedom, 249.

${ }^{21}$ Summa Contra Gentiles, 1:66:10. 
respect; it has no fully determining causes; and it has no being in itself because both or all possible choices have the same 'being' (which is in fact non-being).

\section{Knowledge and Time}

A similar point has been raised about God's knowledge of the future generally-is the future itself unreal, and therefore unknowable? Some, like Alan Padgett, hold that it is. Padgett quotes among those who agree with him the late A.N. Prior ('The present simply is the real considered in relation to two particular species of unreality; namely the past and the present');22 and, more unexpectedly, Hegel ('In the positive meaning of time, it can only be said that the Present is, that Before and After are not'). ${ }^{23}$ And if the future is not real, perhaps God cannot know it, as there is nothing there to be known. This would make theodicy's position much stronger. of course.

I believe that this argument is mistaken, however. There is a trivial sense in which only present events are real, because 'are' is a tensed word, and only applies to present things. The result of the next General Election will be real, but is not yet. Similarly, only living policemen have the power of arrest, because 'have' is a tensed word. But this is nothing to do with the nature of powers of arrest. Past and future policemen are not particular species of those not entitled to arrest anyone. On the contrary, they are precisely those who did have or will have power to arrest, in contrast to the rest of us. Nor is the trivial truth about present events anything to do with the nature of reality. And indeed this is obvious when you consider, firstly, the sort of things to which we can apply the term 'real'. Writers of science fiction frequently describe 'futures' which are unreal, because they are not the same as the real future. Similarly, an historical novelist is not describing the real past, only an imaginary one. And secondly the past is on this view unreal too; but even we can know the past, and

22'The Notion of the Present', cited in A. Padgett, God, Eternity and the Nature of Time (London: Macmillan, 1992) 5.

23Philosophy of Nature, 39, cited by Padgett, loc. cit. 
assuredly God can, and does. If God cannot know the future, it is not because the future is unreal.

\section{Knowledge and Eternity}

I think, however, that there is a related problem concerning the knowledge God has of the future. As I have said, I believe that God is in no sense in time; that he created time, and is in himself timeless. In that case, as far as God is concerned there is no such thing as the future (though of course he knows that for you and me there can be such a thing, just as he knows we have a left and a right, although he himself does not). Peter Geach objected that this entailed one of two intolerable alternatives: either 'God is unaware of the temporal aspect of things, which is so important to us... [or] things really are simultaneous, just as God sees them to be, and... our consciousness of things as successive is a misperception.'24 (Strictly speaking, God does not perceive things to be 'simultaneous'; that too is a word demanding time. Padgett's 'Zero Time Related' is more accurate. But this does not affect the argument.) The latter notion Geach rightly rejects, and gives good reasons for doing so. But the former is simply dismissed: 'I need not linger on this alternative.' It has, however, been seriously advocated. It played an important part in the debate between Algazel (criticising chiefly Avicenna) and Averroes, and it has resurfaced in modern times. If, said Avicenna, you know that one definite eclipse precedes another, this knowledge of yours holds during, before, and after the eclipse. But if you know at one moment that the eclipse is not going on and at another that it is, then your knowledge is alterable. But God is unalterable. He can never, then, refer anything to this or that definite time (in the sense of 'past' 'present' or 'future', that is; of course, he can perfectly well refer it to the year 1900).25 Indeed, I understand that Sorabji has argued not only that God cannot know a falling sparrow needs his concern now but also that he cannot know when to intervene in human affairs, e.g., by sending his Son. ${ }^{26}$ This does not follow. He cannot know that

${ }^{24}$ God and the Soul (London: Routledge, 1969) 92.

${ }^{25}$ Quoted by van den Bergh, Tahafut al-Tahafut, Vol. II, 151.

${ }^{26}$ Quoted by Zagzebski, The Dilemma of Freedom and Foreknowledge, $52 \mathrm{ff}$. 
'now' is the time for the Son to become incarnate, but he can know that he should do so in the reign of Herod the Great.

This is not the time to go further into the matter of God's eternity. But it is relevant to our present topic. For if God is timeless, then his knowledge of the future (and of the past), though very unlike our knowledge by experience, is at least in a way analogous; he is aware of the whole spread of time in rather the way we are aware of a whole (though limited) spread of space. But if God is, as Padgett for instance supposes, only relatively timeless-outside our measured time but with his own present, a past, and a future-then it is very hard to see any analogy that will help us understand his knowledge of the future. For though the future is real, experience of it is not. Nor indeed is experience of the past; but then we have an analogy there in knowledge by memory. The only possibility I can think of (suggested to me by R.R. Cook) is that God has a reverse memory, a pre-memory if you like. There would then be a kind of analogy with our own mundane memories.

We may have to give up the quest for analogies. 'The assumption behind the question [how God can know future contingent truths] seems', writes Craig, 'to be that all genuine knowledge of particulars is based upon immediate perception or causal inference... The objection seems to suffer from anthropomorphism.'27 This is correct. But I think we ought at least to try to find anthropomorphic analogies. If we simply say that God is so different from us that we cannot talk about his knowledge, we have started on a slippery slope: does this also apply to his justice or his love?

Paradoxically, if God is so unlike us as to be timeless, his knowledge of the future is not less comprehensible than if he is in time, but more. Indeed, the theory of divine timelessness has another advantage. If God is in time, and has perfect knowledge of the future, then his life must have the curious property of changing in one respect, namely, his perception of past, present and future-and in no other way whatever (except-again a point made to me by Cook-in so far as his knowledge as he looks forward to the future may be tinged with pleasant or unpleasant feelings, which are not quite the same as the feelings with which his knowledge of the past or the present would be tinged). He knows all things, from his

${ }^{27}$ God, Time and Knowledge, 95. 
infinite past to his infinite future. He knew in 1066 all that would happen in 1815, such as all the details of Napoleon's escape from Elba; the one thing he did not know (for it was not then true) was that 1815 was actually present. Then, in 1815, he knew it was present; now he knows it is past. It seems a curiously futile kind of change. Especially as it includes foreknowledge of all his own actions. He is for ever in the position of Mitt, knowing what he is going to do, but having to wait to do it in actuality. However, I have criticised the idea that one can defend 'middle knowledge' by pointing out theological advantages, and must not go in for that sort of thing myself.

Some would get round this by denying that God has any knowledge of the future directly. He knows what will happen only when it is determined either by laws (and can be known by inference) or by his own intentions. Something like this is held by Swinburne. ${ }^{28}$ He does not, I think, include the former class; and he is correct, though not just for the reasons he gives (basically, that God may choose to alter the laws of nature, or to end the world). Rather, the amount God can know this way is very limited. This is one place where chaos theory is theologically relevant. If some human actions are free, and if quantum events are undetermined, and if a very small difference in initial conditions (such as one brought about by a free action or a quantum event) can have results that rapidly escalate, then not even God can infer what those results will be until the initial choice or quantum event has happened. Even if Mascall is right (which I very much doubt) in denying that quantum events are undetermined as far as God is concerned, we still have the results which flow from free human actions. And if God's own intentions for the future take into account human actions and their consequences, knowledge by intention is also restricted. God's knowledge of the future, on such a theory, is very limited indeed; certainly cases like our Lord's knowledge of Peter's denials are ruled out. If God knows much of the future (as Christians have usually supposed) it must be by direct, unmediated knowledge; and in that case he is surely omniscient.

${ }^{28}$ The Coherence of Theism (2nd ed.) 180-81. 


\section{Conclusion}

We began by wondering whether we needed to ascribe to God knowledge that is different in kind from ours, so different that our knowledge can give us no clue to its nature. (That it is enormously different in all sorts of ways, such as extent or clarity, is not in dispute.) The conclusion seems to be that we do not; that the one sort of knowledge sometimes ascribed to him that is wholly alien to us, middle knowledge, is not in fact a reality even in God, and that the divine knowledge of future contingent facts is amenable to anthropomorphic analogies provided God is timeless. If, however, he is not timeless, then we have three, perhaps four possible moves. We can deny that he is omniscient-indeed, assert that his knowledge of the future is surprisingly limited. Or we can deny that there are any such things as future contingents, insisting on total determinism (even, I suspect, for God himself). Or we can say that he has one kind of knowledge that is wholly unlike anything we have; perhaps (this is our fourth choice) taking this further by denying that any fruitful parallels can be drawn between his knowledge and ours. If none of these seems particularly attractive, this will be some additional reason for believing God to be timeless as well as omniscient. 